\title{
HUBUNGAN ANTARA BODY IMAGE DAN JENIS KELAMIN TERHADAP POLA MAKAN PADA REMAJA
}

\author{
Devi Anis Ramonda, Yunita Galih Yudanari, Zumrotul Choiriyah* \\ Program Studi Keperawatan, Fakultas Keperawatan Universitas Ngudi Waluyo Ungaran \\ *Email: zumrotulnwu@gmail.com
}

\begin{abstract}
ABSTRAK
Pola makan remaja saat ini sudah mulai bergeser pada pola makan yang tidak seimbang sehingga meningkatkan kejadian obesitas pada remaja. Salah satu faktor yang mempengauhi pola makan pada remaja yaitu body image, dan jenis kelamin. Penelitian ini bertujuan untuk mengetahuihubungan antara body image dan jenis kelamin terhadap pola makan pada remaja di SMA Negeri 1 Ungaran. Jenis penelitian ini adalah Diskriptive Korelasional dengan menggunakan pendekatan Cross Sectional. Teknik pengambilan sampel yang digunakan adalah Proportinate Random Sampling dengan total populasi 1212 siswa dan jumlah sampel 92 siswa. Analisi data menggunakan Uji Chi Square. Hasil penelitian menunjukkan bahwa body image pada siswa SMA N 1 Ungaran dalam kategori positif60 responden $(65,2 \%)$. Hasil penelitian didapatkan 56 orang berjenis kelamin perempuan $(60,9 \%)$. Pola makan siswa dalam kategori kurang baik 61 responden (66,3\%). Hasil uji chi squaretentang hubungan body image terhadap pola makan didapatkan $p$ value sebesar $0,047<\alpha(0,05)$. Hasil uji chi squaretentang hubungan jenis kelamin terhadap pola makan didapatkan $\mathrm{p}$ value sebesar $0,048<\alpha$ $(0,05)$. Terdapat hubungan yang bermakna antara body image dan jenis kelamin terhadap pola makan pada remaja di SMA N 1 Ungaran. Diharapkan sekolah dapat memberikan konseling kepada siswanya mengenai pentingnya pola makan yang baik dan benar.
\end{abstract}

Kata kunci: Body image, jenis kelamin, pola makan, remaja

\section{THE CORRELATION BETWEEN BODY IMAGE AND GENDER TO FOOD PATTERN IN ADOLESCENCE}

\begin{abstract}
Understanding the experience of mental illness patient after being given guided imagery is important because guided imagery is one of suggested modality therapy that used to change the behavior of mental patients who had maladaptive behavior to be adaptive. This research aim is to explore information related to experiences of mental patients when relaxation guide imagery is performed. The study was a qualitative method with narrative inquiry method. The researcher conducted the study at Surakarta mental hospital for two months. The samples were16 mental illness patient who has never received guided imagery therapy before and was taken by non-probability sampling. The data were taken by in-depth interview and observation toward the respondent. Thematic analysis was used to analyze the data. The results of the theme identification found two main themes related to the experience of patients with mental disorders when given guided imagery therapy. Those themes are Risk for other-directed Violence and Feeling Convenience.
\end{abstract}

Keywords: Experience, mental illness, guided imagery

\section{PENDAHULUAN}

Pola makan remaja saat ini sudah mulai bergeser kepada pola makan yang tidak seimbang (Samiadi, 2017). Menurut Moehji (2013), kesukaan yang berlebihan remaja terhadap makanan tertentu dapat menyebabkan kebutuhan gizi tidak terpenuhi. Keadaan ini berkaitan dengan "mode" yang tengah marak di kalangan remaja seperti makanan siap saji dan mie instan. Usia remaja merupakan usia yang sangat mudah terpengaruh oleh teman pergaulan dan media masa terutama iklan yang 
menarik perhatian remaja tentang makanan yang baru dan harga yang terjangkau.

Berdasarkan data hasil Riset Kesehatan Dasar tahun 2013 prevalensi remaja kurus relatif sama sedangkan untuk obesitas meningkat. Secara Nasional prevalensi kurus pada remaja umur 16-18 tahun sebesar 9,4\% (1,9\% sangat kurus dan 7,5\% kurus). Prevalensi gemuk pada remaja umur 16-18 tahun sebanyak 7,3\% yang terdiri dari $5,7 \%$ gemuk dan $1,6 \%$ obesitas. Secara lebih rinci prevalensi remaja kurus relatif sama tahun 2007 dan 2013, dan prevalensi sangat kurus naik $0,4 \%$. Sebaliknya prevalensi gemuk naik dari $1,4 \%$ (2007) menjadi 7,3\% (2013) (DepKes RI, 2013)

Body image merupakan penilaian seseorang tentang ukuran tubuh, penampilan dan fungsi setiap bagian tubuhnya (Kozier, 2014). Menurut Sprinthall \& Collins (1995); dalam Potts, et all (2012) bahwa pikiran remaja tentang diri mereka berhubungan dengan tubuh mereka. Remaja yang menggunakan persepsi atau pikiran mereka mengenai body image positif sering dengan kebiasaan atau pola makan yang baik. Timbulnya body image negatif dapat mengakibatkan gangguan citra tubuh. Gangguan pada body image dapat berupa perasaan tidak puas terhadap perubahan struktur, bentuk dan fungsi tubuh. Seseorang yang memiliki body image negatif akan memiliki penilaian yang negatif pula terhadap kondisi tubuhnya dan menganggap kondisi tubuhnya sebagai sesuatu yang tidak menarik bagi orang lain. Oleh karena itu, dirinya perlu melakukan suatu cara untuk merubah penampilan. Salah satu upaya yang dilakukan adalah melalui perilaku diet.

Variasi asupan makanan dapat dipengaruhi oleh jenis kelamin dimana terdapat perbedaan konsumsi makan antara laki-laki dan perempuan. Menurut Depkes (2008), jenis kelamin menunjukkan perbedaan seks yang di dapat sejak lahir yang dibedakan antara lakilaki dan perempuan. Jenis kelamin merupakan faktor internal kebutuhan gizi seseorang. Menurut Gibney, et all, (2015), laki-laki cenderung menyukai makanan yang tinggi lemak, karbohidrat, protein, gula dan alkohol, sedangkan perempuan lebih menyukai makanan seperti buah, sayur dan produk rendah lemak sehingga tidak heran jika terjadi defisiensi makronutrien pada wanita.

SMA N 1 Ungaran Kabupaten Semarang merupakan salah satu sekolah menengah atas favorit di Kabupaten Semarang dengan jumlah tenaga pengajar sebanyak 63 guru, jumlah siswa sebanyak 1212 siswa yaitu 400 siswa laki-laki dan 812 siswa perempuan. Seiring dengan kebijakan pemerintah yang menetapkan lima hari belajar ternyata tidak semuamemberikan dampak yang positif bagi siswa. Siswa harus berangkat pagi-pagi dan pulang di sore hari selama lima hari. Kebijakan tersebut menyebabkan kesempatan mereka untuk sarapan sangat terbatas, apalagi mereka yang rumahnya jauh dari sekolah. Mereka yang bisa sarapan biasanya dengan menu siap saji misalnya mie instan atau makanan instan lainya yang biasanya rendah akan serat. Di siang hari mereka harus mengkonsumsi makanan yang ada dijajakan di kantin sekolah yang nota bene juga tidak dekat dengan gizi seimbang karena yang dijajakan bisanya bakso atau soto.

Peneliti melakukan studi pendahuluan dengan melakukan pengumpulan data terkait dengan body image, jenis kelamin dan pola makan siswa dengan menggunakan kuesioner sederhana terhadap 8 orang siswa. Peneliti mendapatkan 5 dari 8 siswa memiliki pola makan kurang baik, dan dari 5 siswa tersebut 3 anak dengan body image yang positif (merasa penampilannya menarik, menganggap semua orang menilai penampilannya menarik dan memperhatikan penampilannya) dan 2 anak dengan body image yang negatif (merasa penampilannya tidak menarik, menganggap semua orang menilai penampilannya tidak menarik dan tidak memperhatikan penampilannya).

Peneliti menemukan 3 dari 8 siswa memiliki pola makan yang baik. Dari 3 siswa tersebut, 2 anak dengan body image yang negatif (merasa penampilannya tidak menarik, menganggap semua orang menilai penampilannya tidak menarik dan tidak memperhatikan penampilannya) dan seorang anak dengan body 
image positif (merasa penampilannya menarik, menganggap semua orang menilai penampilannya menarik dan memperhatikan penampilannya). Hasil studi pendahuluan tersebut menunjukkan bahwa 3 siswa yang mempunyai pola makan kurang baik meskipun siswa tersebut memiliki body image yang positif, dan terdapat 2 siswa yang memiliki pola makan baik walaupun siswa tersebut dengan body image negatif.

Peneliti menemukan 5 dari 8 siswa memiliki pola makan kurang baik. Dari 5 siswa tersebut 3 anak perempuan dan 2 anak laki-laki. Peneliti juga menemukan 3 dari 8 siswa memiliki pola makan yang baik. Dari 3 siswa tersebut, 2 anak perempuan dan seorang laki-laki. Hasil studi pendahuluan tersebut menunjukkan bahwa 3 siswa perempuan mempunyai pola makan yang buruk meskipun siswa tersebut memiliki body image yang positif, dan terdapat 2 siswa perempuan memiliki pola makan baik walaupun siswa tersebut dengan body image negatif. Berdasarkan fenomena di atas, maka peneliti tertarik untuk melakukan penelitian yang bertujuan untuk mengetahui hubungan antara body image dan jenis kelamin terhadap pola makan pada remaja di SMA N 1 Ungaran Kabupaten Semarang melalui penelitian kuantitatif.

\section{METODE}

Jenis penelitian ini adalahdeskriptif korelasional, dengan menggunakan pendekatan cross sectional. Penelitian ini dilaksanakan di SMA N 1 Ungaran Kabupaten Semarang pada 11 dan 14 Januari 2019. Populasi dalam penelitian ini adalah remaja di SMA N 1 Ungaran Kabupaten Semarang sebanyak 1212 siswi, besar sampel dalam penelitian yang diambil oleh peneliti adalah sebanyak 92 orang.Metode pengambilan sampel dalam penelitian ini adalah dengan cara proportionate random sampling. Alat pengumpulan data yang digunakan dalam penelitian ini yaitu dengan menggunakan kuesioner.

\section{HASIL}

Hasil penelitian terkait Gambaran Body Image Remaja disajikan pada tabel berikut.

Tabel 1.

Distribusi frekuensi berdasarkan body image $(\mathrm{n}=92)$

\begin{tabular}{lcc}
\hline Body image & f & $\%$ \\
\hline Negatif & 32 & 34,8 \\
Positif & 60 & 65,2 \\
\hline
\end{tabular}

Tabel 2.

Distribusi frekuensi berdasarkan jenis kelamin $(n=92)$

\begin{tabular}{|c|c|c|}
\hline Jenis kelamin & $\mathrm{f}$ & $\%$ \\
\hline Perempuan & 56 & 60,9 \\
\hline Laki-laki & 36 & 39,1 \\
\hline
\end{tabular}

Tabel 3.

Distribusi frekuensi berdasarkan pola makan pada remaja $(\mathrm{n}=92)$

\begin{tabular}{lcc}
\hline \multicolumn{1}{c}{ Pola makan } & f & $\%$ \\
\hline Kurang Baik & 61 & 66,3 \\
Baik & 31 & 33,7 \\
\hline
\end{tabular}

Berdasarkan Tabel 1 menunjukkan body image remaja di SMA N 1 Ungaran sebagian besar kategori positif yaitu sebanyak 60 responden $(65,2 \%)$. Tabel 2 menunjukkan jenis kelamin remaja di SMA N 1 Ungaran sebagian besar perempuan yaitu sebanyak 56 responden
(60,9\%). Tabel 3 menunjukkan pola makan pada remaja di SMA N 1 Ungaran Kabupaten Semarang sebagian besar kategori kurang baik yaitu sebanyak 61 responden $(66,3 \%)$. 
Tabel 4.

Hubungan body image dengan pola makan pada remaja $(\mathrm{n}=92)$

\begin{tabular}{|c|c|c|c|c|c|c|c|}
\hline \multirow{3}{*}{ Body image } & \multicolumn{6}{|c|}{ Pola makan } & \multirow{3}{*}{ p value } \\
\hline & \multicolumn{2}{|c|}{ Kurang } & \multicolumn{2}{|c|}{ Baik } & \multicolumn{2}{|c|}{ Total } & \\
\hline & $\mathrm{f}$ & $\%$ & $\mathrm{f}$ & $\%$ & $\mathrm{f}$ & $\%$ & \\
\hline Negatif & 26 & 81,2 & 6 & 18,8 & 32 & 100 & 0,047 \\
\hline Positif & 35 & 58,3 & 25 & 41,7 & 60 & 100 & \\
\hline
\end{tabular}

Tabel 5.

Hubungan Jenis Kelamin dengan Pola Makan pada Remaja

\begin{tabular}{|c|c|c|c|c|c|c|c|}
\hline \multirow{3}{*}{ Jenis Kelamin } & \multicolumn{6}{|c|}{ Pola makan } & \multirow{3}{*}{$\mathrm{p}$ value } \\
\hline & \multicolumn{2}{|c|}{ Kurang } & \multicolumn{2}{|c|}{ Baik } & \multicolumn{2}{|c|}{ Total } & \\
\hline & $\mathrm{f}$ & $\%$ & $\mathrm{f}$ & $\%$ & $\mathrm{f}$ & $\%$ & \\
\hline Perempuan & 42 & 75,0 & 14 & 25,0 & 56 & 100,0 & 0,048 \\
\hline Laki-laki & 19 & 52,8 & 17 & 47,2 & 36 & 100,0 & \\
\hline Jumlah & 61 & 66,3 & 31 & 33,7 & 92 & 100,0 & \\
\hline \multicolumn{3}{|c|}{$\begin{array}{l}\text { Berdasarkan hasil analisis hubungan antara } \\
\text { body image dengan pola makan pada remaja } \\
\text { di SMAN } 1 \text { Ungaran Kabupaten Semarang, } \\
\text { diperoleh hasil responden yang mempunyai }\end{array}$} & \multicolumn{5}{|c|}{$\begin{array}{l}\text { responden puas dengan bentuk dan kondisi } \\
\text { wajahnya saat ini. Menurut Levine\& Smolak } \\
\text { (dalam Diana, 2009), beberapa faktor yang } \\
\text { mempengaruhi body image diantaranya jenis } \\
\text { kelamin. }\end{array}$} \\
\hline
\end{tabular}

orang dimana sebagian besar mempunyai pola makan kategori kurang baikyaitu sebanyak 35 orang $(58,3 \%)$ lebih banyak dari pada kategori baik yaitu sebanyak 25 orang $(41,7 \%)$. Diperoleh hasil responden yang mempunyai body image kategori negatif sebanyak 32 orang dimana sebagian besar mempunyai pola makan kategori kurang baik yaitu sebanyak 26 orang $(81,2 \%)$ lebih banyak dari pada kategori baik yaitu sebanyak 6 orang $(18,8 \%)$. Hasil uji statistik dengan menggunakan uji chi square didapatkan pvalue sebesar $0,047<\alpha(0,05)$, maka dapat disimpulkan ada hubungan yang bermakna body image dengan pola makan pada remaja di SMA N 1 Ungaran Kabupaten Semarang.

\section{PEMBAHASAN}

\section{Gambaran body image remaja}

Hasil penelitian menunjukkan body image remaja di SMA N 1 Ungaran Kabupaten Semarang kategori positif yaitu sebanyak 60 orang $(65,2 \%)$. Berdasarkan jawaban dari responden yang memiliki body image positif ada $(67,4 \%)$ yang setuju bahwa secara keseluruhan penampilannya menarik. Responden yang memiliki body image positif ada $(51,1 \%)$ yang tidak setuju bahwa responden dalam kategori kelebihan berat badan. Responden yang memiliki body image positif ada $(57,6 \%)$ yang setuju bahwa
Hasil penelitian menunjukkan bahwa responden yang mempunyai body image positif sebanyak 60 siswa dimana yang berjenis kelamin perempuan $(68,4 \%)$ dan berjenis kelamin laki-laki (31,6\%). Siswa yang mempunyai jenis kelamin perempuan cenderung lebih memperhatikan tentang body imagenya. Mereka akan merasa terganggu jika memiliki body yang tidak sesuai dengan orang yang diidolakan.

\section{Gambaran jenis kelamin pada remaja}

Hasil penelitian menunjukkan jenis kelamin remaja di SMA N 1 Ungaran Kabupaten Semarang sebagian besar perempuan yaitu sebanyak 56 responden $(60,9 \%)$, lebih banyak dari pada remaja laki-laki yaitu sebanyak 36 orang $(39,1 \%)$. Hal tersebut menunjukkan jenis kelamin remaja di SMA N 1 Ungaran Kabupaten Semarang yang menjadi responden dalam penelitian ini sebagian besar perempuan.

Faktor jenis kelamin dapat terjadi karena adanya perbedaan konsumsi antara anak lakilaki dan anak perempuan. Kebutuhan gizi dan energi antara laki-laki dan perempuan sangat berbeda, hal ini disebabkan karena pertumbuhan dan perkembangan laki-laki dan perempuan juga berbeda. Dimana laki- 
laki memiliki massa otot yang lebih besar dibandingkan perempuan (Depkes, 2008).

\section{Gambaran Pola Makan pada Remaja}

Hasil penelitian menunjukkan pola makan pada remaja di SMA N 1 Ungaran Kabupaten Semarang sebagian besar kategori kurang baik yaitu sebanyak 61 responden $(66,3 \%)$, lebih banyak daripada kategori baik yaitu sebanyak 31 orang $(33,7 \%)$. Hal tersebut menunjukkan pola makan pada remaja di SMA N 1 Ungaran Kabupaten Semarang sebagian besar kategori kurang baik. Pola makan pada remaja kategori kurang baik ditunjukkan dengan responden menyatakan pola makan (sarapan, makan siang, makan malam) dalam waktu yang sama setiap harinya, siswa banyak yang mengatakan tidak sebanyak $(77,2 \%)$, dan siswa mengatakan ya untuk seringmengkonsumsi mi instan sebanyak $(63,0 \%)$.

Menurut Sulistyoningsih (2011), faktor yang mempengaruhi terbentuknya pola makan, diantaranya faktor ekonomi.Variabel ekonomi mencukup dalam peningkatan peluang untuk daya beli pangan dengan kuantitas dan kualitas dalam pendapatan menurunan daya beli pangan secara kualitas maupun kuantitas masyarakat. Pendapatan yang tinggi dapat mencakup kurangnya daya beli dengan kurangnya pola makan masyarakat sehingga pemilihan suatu bahan makanan lebih di dasarkan dalam pertimbangan selera dibandingkan aspek gizi. Kecenderungan untuk mengkonsumsi makanan impor (Sulistyoningsih, 2011).

\section{Hubungan Body Image dengan Pola Makan pada Remaja}

Hasil uji statistik dengan menggunakan uji chi square didapatkan pvalue sebesar $0,047<$ $\alpha(0,05)$, maka dapat disimpulkan ada hubungan yang bermakna body image dengan pola makan pada remaja di SMA N 1 Ungaran Kabupaten Semarang. Timbulnya body image negatif dapat mengakibatkan gangguan citra tubuh. Gangguan pada body image dapat berupa perasaan tidak puas terhadap perubahan struktur, bentuk dan fungsi tubuh. Seseorang yang memiliki body image negatif akan memiliki penilaian yang negatif pula terhadap kondisi tubuhnya dan menganggap kondisi tubuhnya sebagai sesuatu yang tidak menarik bagi orang lain. Oleh karena itu, dirinya perlu melakukan suatu cara untuk merubah penampilan. Salah satu upaya yang dilakukan adalah melalui perilaku diet.

\section{Hubungan Jenis Kelamin dengan Pola Makan pada Remaja}

Hasil uji statistik dengan menggunakan uji chi square didapatkan pvalue sebesar 0,048 < $\alpha(0,05)$, maka dapat disimpulkan ada hubungan antara jenis kelamin dengan pola makan pada remaja di SMA N 1 Ungaran Kabupaten Semarang. Jenis kelamin merupakan faktor yang dapat membedakan pola konsumsi makan. Pertumbuhan, perkembangan, dan massa otot individu sangat berbeda antara laki-laki dan perempuan. Sehingga, menyebabkan laki-laki memiliki pola konsumsi makan lebih banyak. dibandingkan perempuan. Oleh sebab itu, peneliti mengambil variabel jenis kelamin untuk melihat perbedaan pola konsumsi makan antara laki-laki dan perempuan.

Terdapat perbedaan konsumsi makan antara laki-laki dan perempuan. Menurut Depkes (2008), kebutuhan gizi antara laki-laki dan perempuan sangat berbeda, karena pertumbuhan danperkembangan laki-laki dan perempuan juga berbeda dimana laki-laki selalu menjadi prioritas dalam keluarga. Menurut Gibney, et all, (2015), laki-laki cenderung menyukai makanan yang tinggi lemak, karbohidrat, protein, gula dan alkohol, sedangkan perempuan lebih menyukai makanan seperti buah, sayur dan produk rendah lemak sehingga tidak heran jika terjadi defisiensi makronutrien pada wanita.

\section{SIMPULAN DAN SARAN \\ Simpulan}

Body image remaja di SMA N 1 Ungaran sebagian besar kategori positif yaitu sebanyak 60 responden (65,2\%).Jenis kelamin remaja di SMA $\mathrm{N} 1$ Ungaran sebagian besar perempuan yaitu sebanyak 56 responden $(60,9 \%)$.Pola makan pada remaja di SMA N 1 Ungaran sebagian besar kategori kurang yaitu sebanyak 61 responden (66,3\%).Ada hubungan yang bermakna body image dengan pola makan pada remaja di SMA N 1 Ungaran, dengan pvalue sebesar $0,047<\alpha(0,05)$.Ada hubungan yang 
bermakna jenis kelamin dengan pola makan pada remaja di SMA N 1 Ungaran, dengan pvalue sebesar $0,048<\alpha(0,05)$.

\section{Saran}

Sebaiknya peneliti selanjutnya meningkatkan hasil penelitian ini dengan mengendalikan faktor lain yang mempengaruhi penelitian ini misanya faktor aktivitas fisik dengan memasukkan sebagai variabel independen sehingga diperoleh hasil penelitian yang lebih lengkap.

\section{DAFTAR PUSTAKA}

Depkes. (2008). Sistem Kesehatan Nasional. Diakses dari www.pppl.depkes.go.id tanggal 1 November 2018.

Depkes, (2013). Profil Kesehatan Indonesia tahun 2013. Jakarta

Diana, 2009. Hubungan Body Image dengan Harga Diri Pada Remaja. Putri. Artikel Universitas Sumatera Utara [Online]. Diakses dari http://repository.usu.ac.id/bitstream/12 3456789/23720/4/Chapter2.pdf. Pada tanggal 5 November 2018.

Gibney MJ, Barrie MM, John MM, Lenore A, (2015)., Gizi Kesehatan Masyarakat. Jakarta : EGC

Kozier, (2014). Fundamental of Nursing,Calofornia :Copyright by.Addist Asley Publishing Company

Moehji, (2013). Ilmu Gizi I. Jakarta : Bratara Karya Aksara.

$\begin{array}{cccc}\text { Sulistyoningsih, (2011). Gizi } & \text { Untuk } \\ \text { kesehatan Ibu } & \text { dan } & \text { Anak. } \\ \text { Yogyakarta:Publisher } & & \end{array}$

Samiadi, 2017. Panduan Pola Makan Sehat untuk Usia Remaja. Diakses 1 Oktober 2018, dari https://hellosehat.com/hidupsehat/nutrisi/diet-pola-makan-sehatuntuk-usia-remaja/.

Potts \& Mandleco. 2012. Pediatric Nursing; Caring for Children and Their
Families. 3rd ed. Clifton Park. New York 